\title{
VARIATIONS IN PHYSICO-CHEMICAL PROPERTIES OF SHALLOW GROUNDWATER AQUIFERS ACROSS RURAL-URBAN DIFFERENTIALS
}

\author{
Tupeleowei ASINGBI \\ Department of Flood and Erosion Control, Ministry of Environment, Bayelsa State, e-mail: asingbitupeleowei@gmail.com

\section{Olufemi DUROWOJU} \\ Department of Geography, Osun State University, Osogbo, Osun State, e-mail: olufemi.durowoju@uniosun.edu.ng
}

\section{Adeyemi OLUSOLA *}

Department of Geography, University of Ibadan, Ibadan, Nigeria, e-mail: olusolaadeyemi.ao@gmail.com

\section{Rotimi OBATERU}

Department of Geography, University of Ibadan, Ibadan, Nigeria, e-mail: obaterurotimi@gmail.com

Citation: Asingbi, T., Durowoju, O., Olusola, A., \& Obateru, R. (2020). Variations in Physico-Chemical Properties of Shallow Groundwater Aquifers Across Rural-Urban Differentials. Analele Universităţii din Oradea, Seria Geografie, 30(1), 53-64. https://doi.org/10.30892/auog.301107-814

\begin{abstract}
The quality of groundwater is controlled mostly by geology, lithology and depth of aquifers. However, anthropogenic activities can also influence the chemical characteristics of groundwater and this relates directly or indirectly to land use/land cover characteristics. To this effect, this study aimed at evaluating the effect of land use/land cover on the quality of shallow groundwater aquifers in Yenagoa City and its Environs, Bayelsa State, Nigeria. Fifteen groundwater samples were collected randomly from each of the urban and rural land use types making a total of 30 water samples from hand-dug wells that tap into shallow aquifers in the study area. The water samples were subjected to laboratory analyses for Temperature (T), $\mathrm{pH}$, Salinity (Sal), Electrical Conductivity (EC), Total Dissolved Solids (TDS), Nitrate $\left(\mathrm{NO}_{3}\right)$, Chloride $\left(\mathrm{Cl}^{-}\right)$, Sulphate ( $\left.\mathrm{SO}_{4}{ }^{2-}\right)$, Total Alkalinity (TA), Total Hardness (TH), Iron ( $\mathrm{Fe}$ ), Manganese (Mn), Fluoride (F) and Arsenic (As). Factor analysis and Independent samples t-test were employed for analyses in the study. The results revealed that all minimum concentrations of physic-chemical contaminants analyzed were recorded in the rural land use type with exception of $\mathrm{pH}$ and Iron $(\mathrm{Fe})$ while all maximum concentrations were recorded in the urban land use type with exception of Fluoride, Sulfate and Total Hardness. Independent samples t-test show that there is a significant difference in the groundwater physico-chemical characteristics between urban and rural land use types.
\end{abstract}

Key words: Land use/Land Cover, physicochemical contaminants, shallow groundwater aquifers 


\section{INTRODUCTION}

The concentration of contaminants in groundwater is largely a function of both natural and anthropogenic activities (Romocea et al., 2018; Beketova et al., 2019). Serious health hazard could be the outcome when such contaminants level exceeds the recommended standards set by water quality regulating bodies like Federal Environmental Protection Agency (FEPA), Environmental Protection Agency (EPA) and World Health Organization (WHO) may result in serious health hazards (USEPA, 2002; Olusola et al., 2017; Herman et al., 2019a, 2019b).

Shallow aquifers are more vulnerable to contamination from various land uses than deep aquifers. The susceptibility of shallow aquifers to contaminants from surface sources depends on the permeability of the overlaying rock/soil units (Narayanan, 2007) and depth to the water table (Ifabiyi, 2008). These factors are variable especially in areas where anthropogenic inputs are remarkable. Yenagoa is underlain by a sedimentary basin characterized by an unconfined aquifer with rainfall being the direct recharge source (Etu-Efeotor and Akpokodje, 1990). The aquifer is sensitive to changes in land use because the water table is close to the surface (about 3-4 m) during the dry season and during the rainy season the water table rises considerably, in some cases to the ground surface. This makes the shallow aquifer in the area vulnerable to contamination from various land use. Rapid urbanization and population growth are the major threat to groundwater contamination (Olusola et al., 2017) especially shallow aquifers as found in the study area. Due to the attendant population increase in the area, unprecedented waste generation and indiscriminate disposal have become major environmental issues. Landfills within Yenagoa and its environs are mostly in the form of uncontrolled residential dumps with refuse piling up with increasing residency time. Solid waste in landfills decomposes and most often than not pollutes underlying groundwater through seepage or percolation (Offodile, 2002). Other threats to shallow aquifers are point sources of pollution such as leaking septic systems, industrial discharge (liquid waste), oil spillage and pipeline vandalisation (Egboka et al., 1989; Majolagbe et al., 2011; Fashae et al., 2019) and saltwater intrusion (Smith, 1988; Postel et al., 1996; Majolagbe et al., 2011; Morris et al., 2003). It has been posited that unpalatable high concentration of salt particularly chloride renders groundwater nonpotable (Majolagbe et al., 2011), while saline water intrusion is mostly enhanced by over-extraction of fresh groundwater resources due to attendant population increase and rapid urbanization of coastal cities (Smith, 1988; Postel et al., 1996). In Morris et al, (2003), it was confirmed that seepage from contaminated surface waters (rivers, lakes and creeks) can also impair the quality of shallow aquifers and that the presence of chloride, sulphate and other inorganic chemicals can be indicators of pollution. However, contaminants introduced at the land surface can readily enter the underlying aquifer and affect nearby wells that are screened near the water table (Eckhardt and Stackberg, 1995; Fashae et al., 2019). Although the movement and fate of subsurface contaminants depend on the rainfall pattern, depth of water table, distance from the source of contamination and soil properties like permeability, the composition of recharge components as well as geology and hydrology of the area, the greatest concern bothers on the number of pollutants present on the land surface.

From the foregoing, this study is aimed at assessing the physico-chemical characteristics of groundwater from shallow aquifers. To effectively achieve this aim, the study will examine the concentrations of physico-chemical parameters of groundwater in the study area based on recommended standards (World Health Organization, WHO); map the spatial distribution of physicchemical characteristics of groundwater across rural-urban differentials.

\section{Study Area}

The study area lies between latitude $4^{\circ} 54^{\prime} \mathrm{N}-5^{\circ} 08^{\prime} \mathrm{N}$ of the Equator and between longitude $6^{\circ} 05^{\prime} \mathrm{E}-6^{\circ} 23^{\prime}$ East of the Greenwich meridian (figure 1). The study area cuts across three Local Government Areas of Bayelsa State, Nigeria. They are Yenagoa, Kolokuma/Opokuma, and Southern Ijaw Local Government Areas. The total land area is $84989 \mathrm{~km}^{2}$. The area under study is bounded by Sagbama Local Government Area in the North, in the South by Ogbia Local Government Area, in 
the West by Ekeremor Local Government Area and in the East by Rivers State. Part of the study area falls within the state capital, Yenagoa.

The study area has an equatorial hot-humid climate which is characterized mainly with wet and dry seasons. The annual rainfall experience is usually between $(2500 \mathrm{~mm}-3000 \mathrm{~mm})$. The mean temperature is $30 \pm 2^{\circ} \mathrm{C}$, relative humidity is $80 \%$ and above (Iloeje, 1972). The vegetation of the area is characterized by rainforest, marshes, back swamps, mangroves and wetlands. The vegetation is comprised of a multitude of evergreen trees that yield tropical hardwoods such as Mahogany and Abura (Macrophylaciliata). The study area lies within the freshwater forest swamps and back swamps geomorphic unit of the Niger Delta. The Niger Delta is an alluvial plain formed by the deposition and build-up of fine-grained sediments eroded and transported to the area by River Niger and its distributaries (streams). The Coastal Plain Sands of the Benin Formation are the main regional and most important aquifer in the study area (Short and Stauble, 1967). Groundwater in the coastal plain sands occurs mainly under phreatic (unconfined) conditions. The lithology of this formation is dominated by loose sands (fine-medium-coarse), while gravel and pebbles constituting minor components. Thin clay horizons and lenses create discontinuities in the vertical and lateral continuity of the porous sands and gravel. This condition results in the presence of local perched aquifers. Rainfall is the direct recharge source of the groundwater (Short and Stauble, 1967; Etu-Efeotor and Akpokodje, 1990).

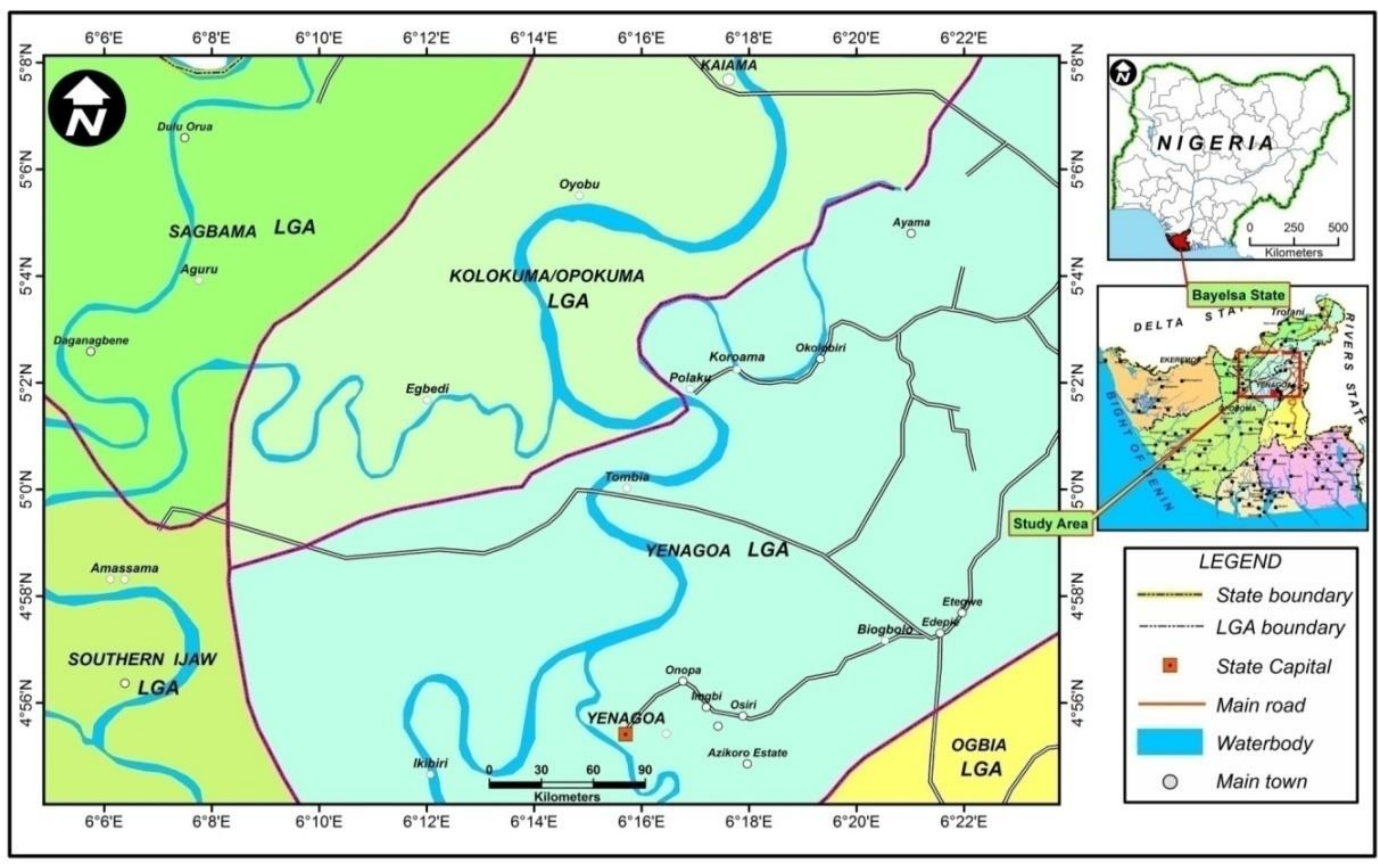

Figure 1. The Study Area Map

Source: Office of The Surveyor General

\section{MATERIALS AND METHODS \\ Water Sampling}

Water samples were collected from wells and kept in 1.5 liter plastic bottles. A total of 15 water samples were collected randomly from each urban and rural land use types in the study area (figure 1) with their respective locations taken with the aid of a GPS (Garmin GPS MAPS $_{78 s}$ ). During sampling, precautions were taken to avoid contamination and to achieve a reflection of the collected sample in the laboratory analyses. 


\section{Laboratory Analysis}

Groundwater samples collected were analyzed in the Central Research Equipment Laboratory (Niger Delta University, Wilberforce Island, Bayelsa State) for Temperature, pH, Salinity, Electrical Conductivity, Nitrate, Chloride, Sulfate, Total Hardness, Total Alkalinity, Iron, Manganese, Fluoride and Arsenic. Temperature, pH, Electrical Conductivity (EC), Salinity of the water samples were measured with the aid of a Wagtech Digital Thermometer/pH Meter/Conductivity/Salinity Meter respectively. The Total Dissolved Solids (TDS) was measured using a JENWAY 3540 Bench TDS meter (UK). Titration method was also used in the determination of Total Hardness and Total Alkalinity. Wagtech Spectrophotometer was used in the determination of Nitrate $\left(\mathrm{NO}_{3}{ }^{-}\right)$and Sulphate $\mathrm{SO}_{4}{ }^{2-}$ at wavelengths of $5000 \mathrm{~nm}$ and $425 \mathrm{~nm}$ respectively. Fluoride and Arsenic concentrations of the water samples were determined using the Atomic Absorption Spectroscopic method. This was done with the aid of the Wagtech UV/VIS Spectrophotometer equipment.

\section{Statistical Analysis}

A simple descriptive statistic summary table was generated from the laboratory results using mean, standard deviation and coefficient of variation of the physic-chemical datasets Independent samples T-test is used to assess the difference in groundwater characteristics between the urban and rural land use types. A plot of loadings of the Factors (components) was done in rotated space to categorize as well as to characterize the hydro-chemical characteristics of the analyzed groundwater parameters in the study area. The SPSS 15.0 (Statistical Product and Service Solutions) was used for the statistical analysis.

\section{RESULTS AND DISCUSSION}

\section{Landuse/land cover classification}

Five major land use types were identified within the study area. These are: minor built-up areas, major built-up areas, open space, vegetation cover and water bodies (figure 2). The minor built-up areas represent the rural/undeveloped areas within the study area (table 1). The rural lands/minor built-up areas accounted for about $1493 \mathrm{~km}^{2}(1.5 \%)$ of the study area (table 1). The dominant activities in this area are farming, fishing and boat making. There is also an existence of a periodic market in the area. The major built-up areas represent the capital city (Yenagoa) where major industrial and commercial activities are predominant. Hence, the major built-up areas represent the urban/developed lands (table 1). The industrial, commercial and landfill areas were all classified under this land use category since they are within the Major Built-up areas. The major built-up areas/urban lands accounted for about $2241 \mathrm{~km}^{2}(2.3 \%$ ) of the study area (table 1, figure 2). This area is closer to the Atlantic Ocean than the minor built-up areas. The Vegetation cover represents the rainforest areas, mangroves, wetlands and swamps within the study area.

Table 1. Land Use/Land Cover Classifications in the Study Area

\begin{tabular}{|c|c|c|c|c|}
\hline $\mathrm{S} / \mathrm{N}$ & Land Use Type & $\left(\mathrm{m}^{2}\right)$ & $\left(\mathrm{Km}^{2}\right)$ & $(\%)$ \\
\hline 1 & Minor built-up area & 14917243 & 1493 & 1.5 \\
\hline 2 & Open space & 2260430 & 226 & 0.2 \\
\hline 3 & Vegetation (mangrove) & 810933596 & 89012 & 91 \\
\hline 4 & Water body & 49026383 & 4904 & 5 \\
\hline 5 & Major built-up area & 22416907 & 2241 & 2.3 \\
\hline
\end{tabular}

This area accounted for about $89012 \mathrm{~km}^{2}$ (91\%) of the study area (table 1, figure 2). This is the largest land use type in the study area. Hunting and lumbering are the predominant activities within this. The open space accounted for the smallest land use type in the study area with an area extent of about $226 \mathrm{~km}^{2}(0.2 \%)$ of the study area. Water Bodies accounted for $4904 \mathrm{~km}^{2}(5 \%)$ of the study area (table 1, figure 2). The Water bodies also accounted for the second-largest land use 
category in the study area. The water bodies in the area include; rivers, lakes, creeks and small streams. The major river in the area is the Nun River which is a network of River Niger. The lakes are Lake Efi, an Ox-bow Lake. The Creeks are Epie and Taylor Creeks. The water bodies are constantly being used for transportation, fishing and recreational purposes. Dumping of solid waste into the water bodies is a regular occurrence especially the creeks (Izonfuo and Bariweni, 2001).

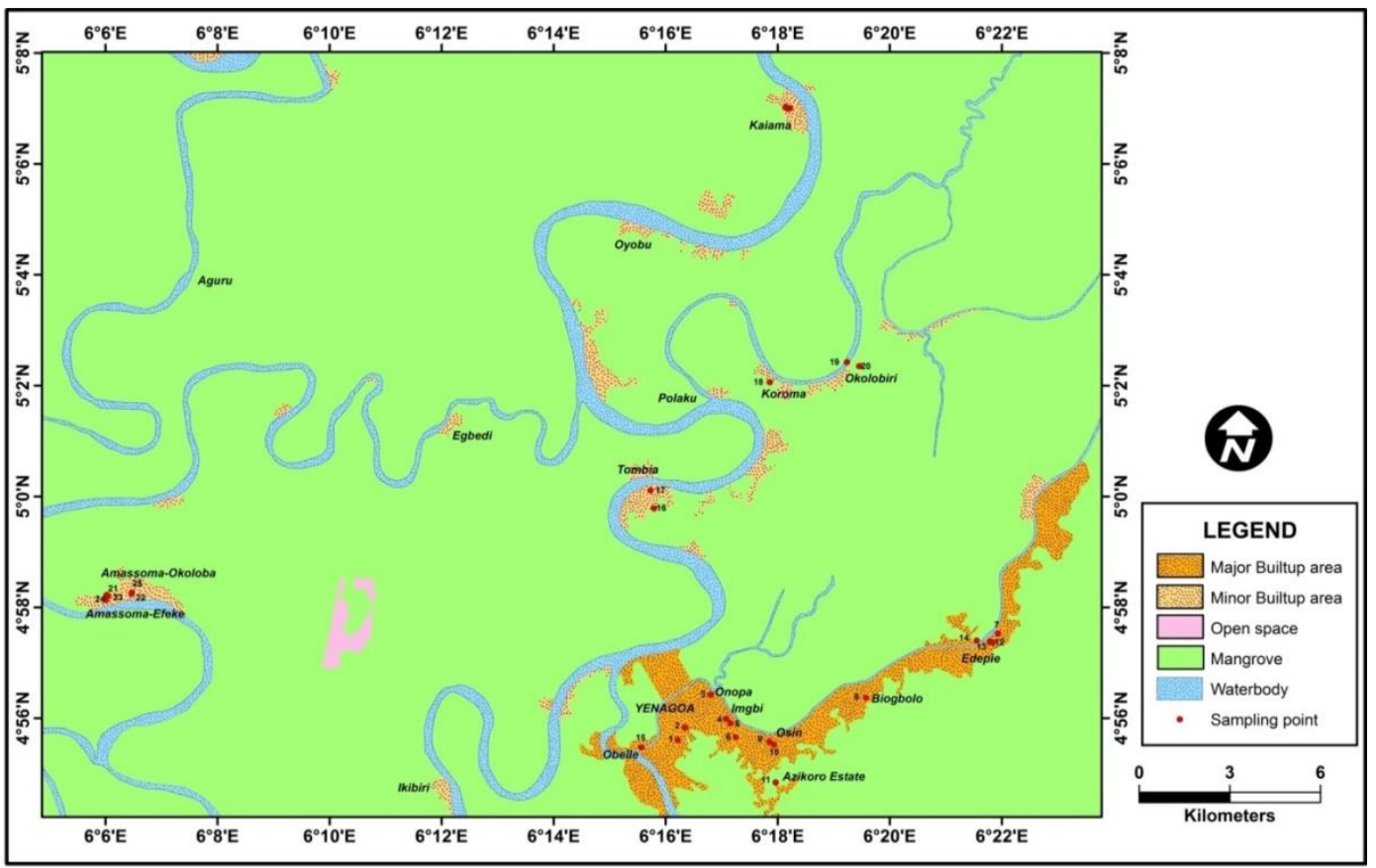

Figure 2. Land use/land cover map of the study area showing sampling points

\section{Physical and Chemical Analysis of Groundwater from the Shallow Aquifers}

From the observed values of $\mathrm{pH}$ in table 2, the minimum and maximum values were 6.97 and 7.6 respectively. It was also observed that both minimum and maximum values of $\mathrm{pH}$ were recorded in the urban land use type. The $\mathrm{pH}$ of all water samples from the shallow aquifers in the study area recorded a mean value of 7.38 (table 2) which is within the recommended drinking water guideline (table 3). These $\mathrm{pH}$ values obtained in the study (table 2) are similar to previously reported values (Nwala et al., 2007; Manilla and Tamuno-Adoki, 2007; Bolaji and Tse, 2009; Chindah et al., 2011) in the Niger Delta region, Nigeria. Saline water intrusion is inevitable since the study area is close to the Atlantic Ocean. It was observed from all the samples that the minimum and maximum salinity levels in the shallow aquifers were $0.02 \mathrm{mg} / \mathrm{l}$ and $0.39 \mathrm{mg} / \mathrm{l}$ respectively (table 2) with a mean value of $0.195 \mathrm{mg} / \mathrm{l}$. The minimum salinity level $(0.02 \mathrm{mg} / \mathrm{l})$ was reported in the rural land use type while the maximum salinity level was reported in the urban land use type. The minimum and maximum electrical conductivity (EC) were $71 \mu \mathrm{s} / \mathrm{cm}$ and $775 \mu \mathrm{s} / \mathrm{cm}$ respectively (table 2). The mean conductivity for all samples in the study area was $405 \mu \mathrm{s} / \mathrm{cm}$ (table 2). It was observed that the minimum conductivity for all samples was recorded in the rural land use type while the maximum conductivity was recorded in the urban land use type. Though there is no recommended guideline for conductivity by WHO (2008), the Standard Organization of Nigeria (2007) recommended a maximum limit of $1000 \mu \mathrm{s} / \mathrm{cm}$ in drinking water supplies. All samples recorded values below this threshold. Electrical conductivity values tend to be slightly high in the study area. This is an indication of high total dissolved solids (TDS). Places that recorded high conductivity also recorded high TDS values. As expected, an increase in dissolved solids will increase conductivity and 
corrosivity of the water. Changes in conductivity with time, or high conductivity values can both indicate that the water has become contaminated (e.g. from saline intrusion, fecal pollution or nitrate pollution). Over time, the contamination can become very inimical to both aquatic life and human beings (Olusola et al., 2017; WHO/UNICEF, 2010; Fashae et al., 2019) and also affect water conduits.

It was observed from the groundwater samples that the minimum and maximum TDS concentrations were $36 \mathrm{mg} / \mathrm{l}$ and $388 \mathrm{mg} / \mathrm{l}$ respectively, with the minimum level $(36 \mathrm{mg} / \mathrm{l})$ been recorded in the rural land use while the maximum level $(388 \mathrm{mg} / \mathrm{l})$ was recorded in the urban land use (table 2). The mean concentration of TDS was $202.9 \mathrm{mg} / \mathrm{l}$. It was generally observed that the TDS concentrations were relatively high which accounts for the high value in EC. High conductivity values were recorded in locations with high TDS values as expected. The high TDS values obtained (table 2) are similar to those reported by (Ozoemenam, 2012; Okiongbo et al, 2014; Fashola, 2013) in the Niger Delta region. It is a known fact that shallow aquifers within this area and the larger Niger Delta region serve as a domestic water supply source especially in communities where these sources are not polluted by hydrocarbons (oil spills). However, the negative effect of consuming water with high TDS is largely inconclusive (WHO, 2008).

The minimum and maximum nitrate concentrations as observed in the collected samples within the study area (table 2) are $0.09 \mathrm{mg} / \mathrm{l}$ and $0.38 \mathrm{mg} / \mathrm{l}$ respectively. The values obtained are similar to those reported by Nwala et al, (2007) and Manilla and Tamuna-Adoki, (2007). A mean concentration of $0.23 \mathrm{mg} / \mathrm{l}$ was recorded within the study area. The minimum and maximum chloride concentrations as observed in the shallow aquifers in the study area are $1.40 \mathrm{mg} / \mathrm{l}$ and $10.50 \mathrm{mg} / \mathrm{l}$ respectively (table 2). The rural land use type in the study area recorded the minimum concentration $(1.40 \mathrm{mg} / \mathrm{l})$ while the urban land use type recorded the maximum concentration $(10.50 \mathrm{mg} / \mathrm{l})$. Chloride concentration in the study area had a mean concentration of $5.32 \mathrm{mg} / \mathrm{l}$. The chloride values obtained (table 2) are within the range of values reported by Ekpete (2002) and Nwala et al., (2007); but are below the values reported by Manilla and Tamuno-Adoki (2007), Bolaji and Tse (2009) in the Niger Delta region. Nitrate and chloride concentrations are all within the acceptable limits (table 3).

It was observed that the minimum and maximum concentrations of Sulphate $\left(\mathrm{SO}_{4}{ }^{2-}\right)$ in the shallow aquifers in the study area are $0.30 \mathrm{mg} / \mathrm{l}$ and $3.80 \mathrm{mg} / \mathrm{l}$ respectively (table 2). Both minimum and maximum concentrations of Sulphate $\left(\mathrm{SO}_{4}{ }^{2-}\right)$ were reported in the rural land use type. A mean concentration of $2.0440 \mathrm{mg} / \mathrm{l}$ was recorded.

The mean concentration of total alkalinity (TA) as observed in (table 2) was $2.33 \mathrm{mg} / \mathrm{l}$. The alkalinity values obtained in the study area (table 2) are below reported values by Koinyan et al., (2013) and Okiongbo et al., (2014) in the Niger Delta region. The total hardness mean concentration in the study area was recorded as $12.54 \mathrm{mg} / \mathrm{l}$ (table 2). Total hardness $(\mathrm{TH})$ values obtained in the study area (table 2) are quite low and are below reported values by Agbalagba et al., (2011), Koinyan et al., (2013) and Okiongbo et al., (2014) in the Niger Delta region. The World Health Organization (WHO) International Standard for Drinking Water (1998) classified water with a total hardness of $\mathrm{CaCO}_{3}<50 \mathrm{mg} / \mathrm{l}$ as soft water, 50 to $150 \mathrm{mg} / \mathrm{l}$ as moderately hard water and water hardness above $150 \mathrm{mg} / \mathrm{l}$ as Hard water. Based on this classification, all water samples in the study area can be regarded are soft water since all values were below $50 \mathrm{mg} / \mathrm{l}$ of $\mathrm{CaCO}_{3}$. The groundwater in the study area is therefore not suitable for drinking based on total hardness. Soft waters with a hardness of less than about $100 \mathrm{mg} / \mathrm{l}$ have a low buffering capacity and may be more corrosive to water pipes (WHO, 2008) which in most cases leaves residues or particulate matter in the water.

As observed in (table 2), Iron (Fe) recorded a minimum and maximum concentration of 0.02 $\mathrm{mg} / \mathrm{l}$ and $0.82 \mathrm{mg} / \mathrm{l}$ respectively. Both minimum and maximum concentrations were reported in urban land use in the study area. Iron $(\mathrm{Fe})$ in the study area recorded a mean concentration of 0.139 $\mathrm{mg} / \mathrm{l}$ for all groundwater samples. As observed in table 2, the minimum and maximum Fluoride concentrations were $0.20 \mathrm{mg} / \mathrm{l}$ and $1.50 \mathrm{mg} / \mathrm{l}$. Both maximum and minimum concentrations of Fluoride were reported in rural land use. A mean concentration of $0.64 \mathrm{mg} / \mathrm{l}$ was recorded which is within the health-based guideline of $1.5 \mathrm{mg} / \mathrm{l}$ recommended by WHO (WHO, 2008). It was observed that the fluoride concentration in the study area is relatively low. This may be as a result of the 
moderate $\mathrm{pH}$ values in the study area. Fluoride increases with a significant increase in $\mathrm{pH}$ (Amini et al., 2007). The minimum and maximum concentrations of Arsenic in the study area were (-0.001 $\mu \mathrm{g} / \mathrm{l})$ and $(0.010 \mu \mathrm{g} / \mathrm{l})$ respectively (table 2$)$. It was observed that Arsenic concentrations in the shallow aquifers of the study area were very low. Some locations gave a negative sign which indicates that the concentration of Arsenic in those locations was below detectable limits. A mean concentration of $0.001433 \mu \mathrm{g} / \mathrm{l}$ was recorded, with a standard deviation and coefficient of variation of 0.0030 and 0.000 respectively. A health-based guideline of $10 \mu \mathrm{g} / \mathrm{l}(0.01 \mathrm{mg} / \mathrm{l})$ is recommended by (WHO, 2008). Elevated concentration of Arsenic in drinking water has some carcinogenic effects.

Table 2. Descriptive statistics of the physical and chemical analysis of groundwater from the Shallow Aquifers in the Study Area

Source: WHO (2008)

\begin{tabular}{|c|c|c|c|c|c|}
\hline Parameters & Minimum & Maximum & Mean & Std Dev. & Coeff. Var \\
\hline $\mathrm{T}\left(\mathrm{T}^{0} \mathrm{C}\right)$ & 25.50 & 27.50 & 26.2503 & .54974 & .302 \\
\hline $\mathrm{pH}$ & 6.97 & 7.60 & 7.3820 & .12702 & .016 \\
\hline SAL (mg/l) & .02 & .39 & .1953 & .09250 & .009 \\
\hline $\mathrm{EC}(\mu \mathrm{scm}-1)$ & 71.00 & 775.00 & 405.333 & 178.570 & 31887.264 \\
\hline TDS (mg/l) & 36.00 & 388.00 & 202.900 & 89.2130 & 7958.972 \\
\hline $\mathrm{NO}_{3}{ }^{-}(\mathrm{mg} / \mathrm{l})$ & .09 & .38 & .2287 & .08072 & .007 \\
\hline $\mathrm{Cl}^{-}(\mathrm{mg} / \mathrm{l})$ & 1.40 & 10.50 & 5.3233 & 2.06493 & 4.264 \\
\hline $\mathrm{SO}_{4}^{2-}(\mathrm{mg} / \mathrm{l})$ & .30 & 3.80 & 2.0440 & 1.03095 & 1.063 \\
\hline $\mathrm{TA}(\mathrm{mg} / \mathrm{l})$ & 1.10 & 4.70 & 2.3367 & .83397 & .696 \\
\hline $\mathrm{TH}(\mathrm{mg} / \mathrm{l})$ & 2.20 & 27.80 & 12.5367 & 5.89614 & 34.764 \\
\hline $\mathrm{Fe}(\mathrm{mg} / \mathrm{l})$ & .02 & .82 & .1387 & .15704 & .025 \\
\hline $\mathrm{Mn}(\mathrm{mg} / \mathrm{l})$ & .00 & .04 & .0182 & .00915 & .000 \\
\hline $\mathrm{F}^{-}(\mathrm{mg} / \mathrm{l})$ & .02 & 1.50 & .6447 & .43042 & .185 \\
\hline As $(\mu \mathrm{g} / \mathrm{l})$ & -.001 & .010 & .00143 & .003002 & .000 \\
\hline
\end{tabular}

Temperature (T), pH, Salinity (Sal), Electrical conductivity (EC), Total Dissolved Solids (TDS), Nitrate $\left(\mathrm{NO}_{3}{ }^{-}\right), \mathrm{Chloride}\left(\mathrm{Cl}^{-}\right)$, Sulphate $\left(\mathrm{SO}_{4}{ }^{2-}\right)$, Total Alkalinity (TA), Total Hardness (TH), Iron (Fe), Manganese (Mn), Fluoride ( $\left.\mathrm{F}^{-}\right)$and Arsenic (As)

Table 3. World Health Organization (WHO) Guidelines Source: WHO (2008)

\begin{tabular}{|c|c|c|c|}
\hline $\mathrm{S} / \mathrm{N}$ & Parameters & Mean & WHO Guidelines \\
\hline 1 & Temperature $\left(\mathrm{T}^{\circ} \mathrm{C}\right)$ & 26.2503 & Not defined \\
\hline 2 & $\mathrm{pH}$ & 7.3820 & $6.5-8.5$ \\
\hline 3 & Salinity $(\mathrm{SAL}) \mathrm{mg} / \mathrm{l}$ & 0.1953 & Not defined \\
\hline 4 & Electrical Conductivity $(\mathrm{EC}) \mu \mathrm{scm}-1$ & 405.3333 & Not defined \\
\hline 5 & Total Dissolved Solids $(\mathrm{TDS}) \mathrm{mg} / \mathrm{l}$ & 202.9000 & 1000 (taste concerns) \\
\hline 6 & Nitrate $\left(\mathrm{NO}_{3}\right) \mathrm{mg} / \mathrm{l}$ & 0.2287 & 50 \\
\hline 7 & Chloride $\left(\mathrm{Cl}^{-}\right) \mathrm{mg} / \mathrm{l}$ & 5.3233 & 250 (taste concerns) \\
\hline 8 & Sulphate $\left(\mathrm{SO}_{4}{ }^{2-}\right)$ & 2.0440 & Not defined \\
\hline 9 & Total Alkalinity $(\mathrm{TA}) \mathrm{mg} / \mathrm{l}$ & 2.3367 & 0.3 \\
\hline 10 & Total Hardness $(\mathrm{TH}) \mathrm{mg} / \mathrm{l}$ & 12.5367 & 200 (scale deposition) \\
\hline 11 & Iron $(\mathrm{Fe}) \mathrm{mg} / \mathrm{l}$ & 0.1387 & 0.4 \\
\hline 12 & Manganese $(\mathrm{Mn}) \mathrm{mg} / \mathrm{l}$ & 0.0182 & 1.5 \\
\hline 13 & Fluoride $\left(\mathrm{F}^{-}\right) \mathrm{mg} / \mathrm{l}$ & 0.6447 & $10 \mu \mathrm{g} / \mathrm{l}(0.01 \mathrm{mg} / \mathrm{l})$ \\
\hline 14 & Arsenic $(\mathrm{As}) \mu \mathrm{g} / \mathrm{l}$ & 0.00143 & \\
\hline
\end{tabular}




\section{Factor analysis of groundwater samples}

Factor analysis (FA) of the studied groundwater samples was performed in other to get an overall impression about assembling the samples in a multi-dimensional space defined by the analyzed parameters. The results were (0.609) for Kaiser-Meyer-Olkin Measure of Sampling Adequacy (KMO) and (566.505) for Bartlett's Test of Sphericity $(\mathrm{p}<0.0001)$. This indicates that the results are significant and that Factor Analysis may be useful in providing significant reductions in dimensionality. From the analysis performed five factors (components) explaining $80.179 \%$ of the total variance were estimated based on Kaiser criterion (Kaiser, 1960) of the eigenvalues greater or equal to one (1) (table 6) and from a Cattel Scree plot. The Scree plot (figure 3) shows the eigenvalues sorted from large to small as a function of the factor number.

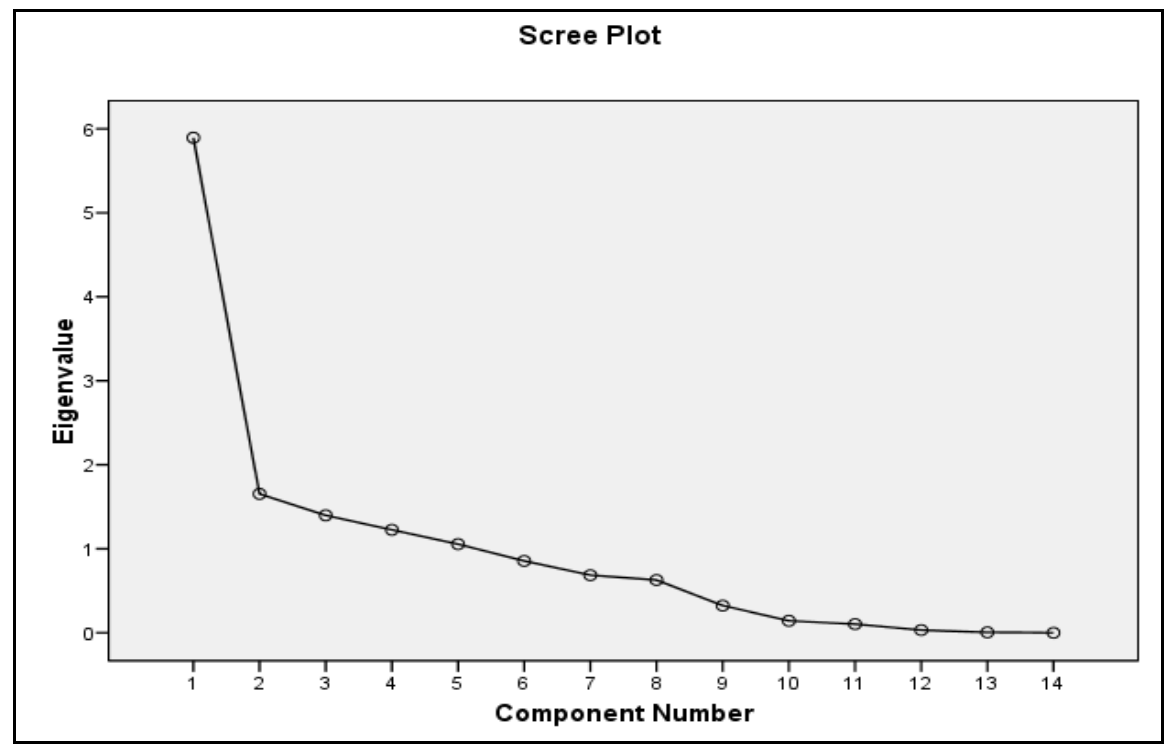

Figure 3. Scree Plot Test

Table 4. Factor loading matrix of physico-chemical parameters

\begin{tabular}{|c|c|c|c|c|c|}
\hline PARAMETERS & \multicolumn{5}{|c|}{ FACTORS } \\
\hline & 1 & 2 & 3 & 4 & 5 \\
\hline $\mathrm{T}$ & .106 & -.140 & .149 & .843 & .064 \\
\hline $\mathrm{Ph}$ & .089 & .602 & .669 & .009 & .256 \\
\hline $\mathrm{SAL}$ & .948 & .015 & .215 & .091 & .108 \\
\hline $\mathrm{EC}$ & .953 & .043 & .210 & .115 & .082 \\
\hline $\mathrm{TDS}$ & .953 & .044 & .210 & .114 & .082 \\
\hline $\mathrm{NO}_{3}$ & .639 & -.077 & .058 & .182 & .304 \\
\hline $\mathrm{Cl}^{-}$ & .888 & .192 & .003 & .087 & -.209 \\
\hline $\mathrm{SO}_{4}{ }^{2-}$ & .819 & .215 & -.144 & .028 & -.200 \\
\hline $\mathrm{TA}$ & .717 & -.120 & .313 & -.177 & .414 \\
\hline $\mathrm{TH}$ & .469 & .304 & -.353 & -.007 & .118 \\
\hline $\mathrm{Fe}$ & -.083 & -.932 & -.008 & -.048 & -.010 \\
\hline $\mathrm{Mn}$ & .299 & -.038 & .819 & .051 & -.120 \\
\hline $\mathrm{F}$ & .125 & .408 & -.152 & .698 & .084 \\
\hline As & .040 & .103 & -.066 & .121 & .890 \\
\hline Eigen value & 5.894 & 1.653 & 1.398 & 1.225 & 1.055 \\
\hline Cumulative $\%$ & 42.099 & 11.810 & 9.983 & 8.752 & 7.535 \\
\hline Variance & 42.099 & 53.910 & 63.893 & 72.644 & 80.179 \\
\hline
\end{tabular}

Temperature (T), pH, Salinity (Sal), Electrical conductivity (EC), Total Dissolved Solids (TDS), Nitrate $\left(\mathrm{NO}_{3}\right)$, $\mathrm{Chloride}(\mathrm{Cl})$, Sulfate $\left(\mathrm{SO}_{4}{ }^{2-}\right)$, Total Alkalinity (TA), Total Hardness (TH), Iron (Fe), Manganese (Mn), Fluoride (F) and Arsenic (As) 
As observed from (table 4), SAL, EC, TDS, $\mathrm{NO}_{3}, \mathrm{C}^{\mathrm{l}-}, \mathrm{SO}_{4}{ }^{2-}$ and TA are marked factor one (1), which explained $42.099 \%$ of the total variance. Factor 1 showed a high positive loading in SAL, EC, TDS, $\mathrm{NO}_{3}, \mathrm{Cl}^{-}, \mathrm{SO}_{4}{ }^{2-}$ and TA. High positive loadings indicate a strong linear correlation between the factor and parameters. Most highly correlated with Factor 1 were SAL, TDS and EC, with TDS and EC recording strong positive loadings. Thus factor 1 can be termed conductivity index. This is an indication that the groundwater in the shallow aquifers in the study area is contained with high levels of dissolved inorganic salts which must have originated from high saline water, possibly saline water intrusion since the study area is close to the Atlantic Ocean. Increased saline intrusion can increase densities of shallow aquifers in the study area and this may in the long run affect ocean circulation. Also, $\mathrm{Cl}^{-}$, Nitrate and $\mathrm{SO}_{4}{ }^{2-}$ are pollutants that help in increasing conductivity and consequently affecting salinity, hence, their correlation is as expected. Dissolved inorganic constituents can also come from leaking septic systems (soak away pits), sewage, urban runoff, leachates from landfills and industrial wastewater (WHO, 2008). Conductivity, especially specific conductance is a first-order measure as regards water quality parameters especially in zones with shallow water aquifers. It is an early indicator of change in a water system. Salinity, as expected, is associated with conductivity and hence, marine organisms' tolerance depends largely on their osmotic processes. Based on their tolerance range, marine organisms (saltwater, euryhaline, anadromous, catadromous and freshwater) respond differently to varying levels of salinity. The varying levels affect the metabolic activities of these organisms. This implies that an increase in SAL, EC and TDS will increase $\mathrm{NO}_{3}, \mathrm{Cl}^{-}, \mathrm{SO}_{4}{ }^{2-}$ and TA in the shallow aquifers in the study area (Liu et al., 2003).

Factor two (2) with a high loading of $\mathrm{pH}$ and Fe explained $11.810 \%$ of the total variance with loadings of 0.602 and -0.932 respectively (table 4). This indicates that factor 2 is positively correlated with $\mathrm{pH}$ but negatively correlated with $\mathrm{Fe}$. This also means that both ( $\mathrm{pH}$ and $\mathrm{Fe}$ ) have an inverse relationship. This again confirms the moderately acidic nature of the groundwater in the study area being neutralized by salt contamination to a large extent (Chindah et al., 2011), therefore resulting in (Fe) having a negative correlation with $\mathrm{pH}$ in factor 2 . This factor can be termed an oxidizing index.

The third factor is strongly correlated with $\mathrm{Mn}$ and $\mathrm{pH}$, which accounted for $9.983 \%$ of the total variance with factor loadings of 0.819 and 0.669 respectively (table 4). It also implies that $\mathrm{Mn}$ and $\mathrm{pH}$ exhibit relationship and as expected this is particularly true of low-relief areas abutting the coast. This can be termed manganese-toxicity index.

Factor four (4) was responsible for $8.752 \%$ of the total variance and strongly correlated with Temperature $\left(\mathrm{T}^{\circ} \mathrm{C}\right)$ and Fluoride $(\mathrm{F})$, with factor loadings of 0.843 and 0.698 respectively. In factor 4 , $\mathrm{T}^{\circ} \mathrm{C}$ showed a strong correlation ahead of Fluoride, implying that $\mathrm{T}^{\circ} \mathrm{C}$ has a strong positive relationship with factor 4 . This can be termed a physical attribute index.

Finally, factor five (5) was correlated with only As, which accounted for just $7.535 \%$ of the total variance with a factor loading of 0.890 (table 4). This indicates that As has a strong positive relationship with factor 5 . The results also reveal that As has no linear relationship with any other parameter in the study area. This indicates that the traces of As concentration in the shallow aquifers in the study area may have originated from other factors. WHO (2008) noted that As may originate from anthropogenic sources, such as sewage, mining and other industrial activities. This factor can be termed an anthropogenic-pollutant index.

In essence, across shallow aquifers in sedimentary basins around coastal regions especially in tropical environments, determination of water quality should focus mostly on conductivity parameters (salinity, electrical conductivity, chloride, sulphate, etc), followed by oxidizing agents such as $\mathrm{pH}$, iron, then manganese-toxicity tests. These three indices account for over $60 \%$ of the total variance in the factor analysis tests (table 8 ). The other two indices, physical attributes and anthropogenic-pollutants, accounts for about $15 \%$. Therefore, water quality studies around this region should focus more on the first three indices in determining the level of water quality (Liu et al., 2003). 


\section{Rural-urban differentials in groundwater quality}

Independent samples T-Test was carried out to examine the difference in shallow groundwater quality between urban and rural land-use types (table 5). The result shows that there is a significant difference in the level of the following parameters: temperature $(\mathrm{t}=2.719, \mathrm{df}=28$, $\mathrm{p}<0.05)$; salinity $(\mathrm{t}=2.182, \mathrm{df}=28, \mathrm{p}<0.05)$; Total Dissolved Solids $(\mathrm{t}=2.371, \mathrm{df}=28, \mathrm{p}<0.05)$; and manganese $(\mathrm{t}=3.894, \mathrm{df}=28, \mathrm{p}<0.05)$. Possible explanations to these observed differences can be tied to rapid urbanization, population density especially in the urban areas (Olusola et al., 2017; Fashae et al., 2019), saltwater intrusion causing significant differences in SAL, TDS, EC and Mn, water recharge source(s) to the shallow aquifers mixed with anthropogenic activities (Liu et al., 2003). Mixing is an important process that influences the chemical composition of groundwater. Mixing occurs when groundwater moving along a specific flow path encounters other water that has evolved independently. If the mixing waters have chemical compositions different from each other, the constituent concentrations and proportions in the resulting mixture will be intermediate to the constituent concentrations and proportions of the original waters. Water that may mix with groundwater includes water from another aquifer e.g., saline groundwater especially in areas very close to the sea; groundwater that has travelled along a different flow path within the same aquifer; and surface water or water-related to human activity that infiltrates into the aquifer. Sources of surface water can include rivers, streams, lakes, reservoirs, canals, and ponds which can have different chemical compositions. Water-related to human activity includes animal, human and food processing wastewater, irrigation water, and other water that have significantly different chemical compositions.

Table 5. Independent Samples T-test for physico-chemical properties across rural-urban areas

\begin{tabular}{|c|c|c|c|c|c|c|c|}
\hline & Location & $\mathrm{N}$ & Mean & Std. Deviation & $\mathrm{T}$ & df & Sig. (2-tailed) \\
\hline \multirow[t]{2}{*}{$\mathrm{T}$} & Urban & 15 & 26.497333 & .6245852 & 2.719 & 28 & .011 \\
\hline & Rural & 15 & 26.003333 & .3242941 & & & \\
\hline \multirow[t]{2}{*}{$\mathrm{PH}$} & Urban & 15 & 7.405333 & .1516512 & 1.006 & 28 & .323 \\
\hline & Rural & 15 & 7.358667 & .0962041 & & & \\
\hline \multirow[t]{2}{*}{ SAL } & Urban & 15 & .230000 & .0935796 & 2.182 & 28 & .038 \\
\hline & Rural & 15 & .160667 & .0799524 & & & \\
\hline \multirow[t]{2}{*}{$\mathrm{EC}$} & Urban & 15 & 477.200000 & 177.5343830 & 2.374 & 28 & .025 \\
\hline & Rural & 15 & 333.466667 & 153.1870317 & & & \\
\hline \multirow[t]{2}{*}{ TDS } & Urban & 15 & 238.766667 & 88.8483593 & 2.371 & 28 & .025 \\
\hline & Rural & 15 & 167.033333 & 76.3924236 & & & \\
\hline \multirow[t]{2}{*}{$\mathrm{NO}_{3}$} & Urban & 15 & .245333 & .0838252 & 1.137 & 28 & .265 \\
\hline & Rural & 15 & .212000 & .0766439 & & & \\
\hline \multirow[t]{2}{*}{$\mathrm{CL}$} & Urban & 15 & 5.886667 & 2.1179055 & 1.528 & 28 & .138 \\
\hline & Rural & 15 & 4.760000 & 1.9149040 & & & \\
\hline \multirow[t]{2}{*}{$\mathrm{SO}_{4}$} & Urban & 15 & 2.242667 & .8575086 & 1.058 & 28 & .299 \\
\hline & Rural & 15 & 1.845333 & 1.1754687 & & & \\
\hline \multirow[t]{2}{*}{ TA } & Urban & 15 & 2.480000 & .6950848 & .939 & 28 & .356 \\
\hline & Rural & 15 & 2.193333 & .9557844 & & & \\
\hline \multirow[t]{2}{*}{$\mathrm{TH}$} & Urban & 15 & 12.466667 & 6.1781489 & -.064 & 28 & .950 \\
\hline & Rural & 15 & 12.606667 & 5.8165364 & & & \\
\hline \multirow[t]{2}{*}{$\mathrm{Fe}$} & Urban & 15 & .176667 & .2053105 & 1.344 & 28 & .190 \\
\hline & Rural & 15 & .100667 & .0763887 & & & \\
\hline \multirow[t]{2}{*}{$\mathrm{Mn}$} & Urban & 15 & .023533 & .0075675 & 3.894 & 28 & .001 \\
\hline & Rural & 15 & .012867 & .0074342 & & & \\
\hline \multirow[t]{2}{*}{$\mathrm{F}$} & Urban & 15 & .710000 & .4009809 & .827 & 28 & .415 \\
\hline & Rural & 15 & .579333 & .4624078 & & & \\
\hline \multirow[t]{2}{*}{ As } & Urban & 15 & .002000 & .0041404 & 1.035 & 28 & .309 \\
\hline & Rural & 15 & .000867 & .0009155 & & & \\
\hline
\end{tabular}

Significant at $\mathrm{p}<0.05$ significance level(2-tailed)

Temperature (T), pH, Salinity (Sal), Electrical conductivity (EC), Total Dissolved Solids (TDS), Nitrate ( $\left.\mathrm{NO}_{3}\right)$, $\mathrm{Chloride}(\mathrm{Cl})$, Sulphate $\left(\mathrm{SO}_{4}{ }^{2-}\right)$, Total Alkalinity (TA), Total Hardness (TH), Iron (Fe), Manganese (Mn), Fluoride (F) and Arsenic (As). 


\section{CONCLUSION}

From the study, it was observed that the concentration of groundwater parameters from shallow aquifers is significantly influenced by seawater intrusion within the study area. The groundwater in the study area is moderately acidic in nature but a possibility of saline water intrusion, is making it alkaline and in turn influencing the chemical characteristics of other groundwater parameters in the study area. An increase in salinity has resulted in an increase in $\mathrm{pH}$ from an acidic state to an alkaline state. The chemical make-up of groundwater within the study area across rural-urban differentials revealed that the determination of water (ground) quality rests on five major indices. There are: conductivity, oxidising, manganese-toxicity, physical attributes and anthropogenic-pollutants. There first three indices (conductivity, oxidizing and manganesetoxicity) account for over $60 \%$ of the variance based on factor analysis. Therefore, this study confirms that within shallow aquifers in sedimentary basins abutting the coast, conductivity, oxidizing and manganese-toxicity indices are the main parameters that should be examined for determining groundwater quality.

There is equally a need for constant monitoring of the underground water quality to ensure that water quality parameters do not build up to levels that will be of environmental concern especially in areas with a growing population and infrastructural developments. There should be a coordinated sampling and monitoring program to check the quality of underground water regularly.

\section{REFERENCES}

Agbalagba, O. E., Agbalagba, O. H., Ononugbo, C. P., \& Alao, A. A. (2011). Investigation into the physico-chemical properties and hydrochemical processes of groundwater from commercial boreholes In Yenagoa, Bayelsa State, Nigeria. African Journal of Environmental Science and Technology, 5(7), 473-481.

Amini, M., Abbaspour, K. C., Berg, M., Winkel, L., Hug, S. J., Hoehn, E., ... \& Johnson, C. A. (2008). Statistical modeling of global geogenic arsenic contamination in groundwater. Environmental science \& technology, 42(10), 3669-3675.

Beketova, A., Berdenov, Z., Mendybayev, E., \& Safarov, R. (2019). Shomanova Zh. \& Herman GV (2019). Geochemical Monitoring of Industrial Center for Development of Recreational Areas (On the Example of Khromtau-Don Industrial Hub, Kazakhstan). GeoJournal of Tourism and Geosites, 27 (4), 1449-1463.

Bolaji, T.A, \& Tse, C.A. (2009). Spatial Variation in Groundwater Geochemistry and Water Quality Index in Port Harcourt. Scientia Africana, 8(1), 134-155.

Chindah, A. C., Braide, S. A., \& Obunwo, C. C. (2011). Water quality of streams receiving municipal wastewater in Port Harcourt, Niger Delta, Nigeria. Waste Water-Evaluation and Management.

Eckhardt, D. A., \& Stackelberg, P. E. (1995). Relation of ground-water quality to land use on Long Island, New York. Groundwater, 33(6), 1019-1033.

Egboka, B. C., Nwankwor, G. I., Orajaka, I. P., \& Ejiofor, A. O. (1989). Principles and problems of environmental pollution of groundwater resources with case examples from developing countries. Environmental health perspectives, 83, 39-68.

Ekpete, O. A. (2002). Determination of Physico-Chemical Parameters in borehole water in Odihologboji community in Rivers State. Afr. J. Interdiscip. Stud, 3(1), 23-27.

Environmental Protection Agency (2002). Current drinking water standards: U.S. Environmental Protection Agency Fact Sheet EPA 816-F-02-013: accessed August 7, 2002, at URL http://www.epa.gov/safewater/mcl.html.

Etu-Efeotor, J.O, \& Akpokodje, E.G (1990). Aquifer Systems of the Niger Delta. J. Min. Geol., 26(2), 279-294.

Fashae, O. A., Ayorinde, H. A., Olusola, A. O., \& Obateru, R. O. (2019). Landuse and surface water quality in an emerging urban city. Applied Water Science, 9(2), 25.

Herman, G. V., Gaceu, O., Mester, C., Baias, S., Caciora, T., \& Wendt, J. A. (2019a). Spatial analysis of water quality in natura 2000 Sites Bihor, Romania. Journal of Environmental Protection and Ecology, 20(4), 2121-2129.

Herman, G. V., Ilies, D. C., Gaceu, O., Ilies, A., Mester, C., Ilies, M., ... \& Dumitru, M. (2019b). Some considerations concerning the quality of groundwater in the Natura 2000 Lunca Barcaului (Barcaului Meadow) site, Romania. Journal of Environmental Protection and Ecology, 20(3), 1102-1109.

Ifabiyi, I. P. (2008). Depth of hand dug wells and water chemistry: Example from Ibadan Northeast Local Government Area (LGA), Oyo-state, Nigeria. Journal of Social Sciences, 17(3), 261-266.

Iloeje, N.P. (1972). A New Geography of West Africa, Longman Group Limited, Nigeria.

Izonfuo, L. W. A., \& Bariweni, A. P. (2001). The effect of urban runoff water and human activities on some physicochemical parameters of the Epie Creek in the Niger Delta. Journal of Applied Sciences and Environmental Management, 5(1), 47-55.

Kaiser, H. F. (1991). Coefficient alpha for a principal component and the Kaiser-Guttman rule. Psychological reports, 68(3), 855-858. 
Koinyan, A. A., Nwankwoala, H. O., \& Eludoyin, O. S. (2013). Water resources utilization in Yenagoa, Central Niger Delta: environmental and health implications. Int. J. Water Res. Environ. Eng., 5(4), 177-186.

Liu, C. W., Lin, K. H., \& Kuo, Y. M. (2003). Application of factor analysis in the assessment of groundwater quality in a blackfoot disease area in Taiwan. Science of the Total Environment, 313(1-3), 77-89.

Majolagbe, A. O., Kasali, A. A., \& Ghaniyu, L. O. (2011). Quality assessment of groundwater in the vicinity of dumpsites in Ifo and Lagos, Southwestern Nigeria. Advances in Applied Science Research, 2(1), 89-29.

Manilla, P. N., \& Tamuno-Adoki, T. (2007). Physical and Chemical Assessment of Okrika River, Okrika LGA Rivers State, Nigeria. Journal of Nigerian Environment and Society, 4(1), 88-94.

Morris, B. L., Lawrence, A. R., Chilton, P. J. C., Adams, B., Calow, R. C., \& Klinck, B. A. (2003). Groundwater and its susceptibility to degradation: a global assessment of the problem and options for management (Vol. 3). United Nations Environment Programme.

Narayanan, P. (2007). Environmental Pollution: Principles, Analysis and Control. CBS Publishers \& Distributors, New Delhi. 659.

Nwala, C. O., Akaninwor, J. O., \& Abbey, B. W. (2007). Physico-chemical parameters of monopumps and well waters in Igbo Etche. J. Nig. Environ. Soc, 4(1), 78-87.

Nwankwoala, H.O, \& Ngah, S.A (2013). Quality Of Groundwater In Deep Aquifer Systems Of The Niger Delta. Caribbean Journal Of Science And Technology. 1,081-097Http://Caribjscitech.Com/

Offodile, M.E. (2002). Groundwater study and development in Nigeria. Mecon Eng. Servies Ltd, Jos, Nigeria, 239-345.

Okiongbo, K. S., \& Douglas, R. (2013). Hydrogeochemical analysis and evaluation of groundwater quality in Yenagoa City and Environs, Southern Nigeria. Ife Journal of Science, 15(2), 209-222.

Olusola, A., Adeyeye, O., \& Durowoju, O. (2017). Groundwater: quality levels and human exposure, SW Nigeria. Journal of Environmental Geography, 10(1-2), 23-29.

Ozoemenam, C.J. (2012). Assessment of Water Quality Of Shallow And Deep Boreholes In Ekpan Community, Effurun, Delta State, Nigeria From Naulibrary.Org/Dglibrary/ ...1101.Pdf/ Retrieved 8th Nov, 2014 At 6:11pm.

Postel, S. L., Daily, G. C., \& Ehrlich, P. R. (1996). Human appropriation of renewable fresh water. Science, 271(5250), $785-788$.

Romocea, T., Oneț, A., Sabău, N. C., Oneț, C., Herman, G. V., \& Pantea, E. (2018). Change of the Groundwater Quality from Industrial Area Oradea, Romania, Using Geographic Information Systems (GIS). Environmental Engineering \& Management Journal (EEMJ), 17(9), 2189-2199.

Short, K. C., \& Stäuble, A. J. (1967). Outline of geology of Niger Delta. AAPG bulletin, 51(5), 761-779.

Smith, Z.A. (1988). Groundwater in the West. New York Academic Press.

Standard Organization of Nigeria (2007). Nigerian Standards for Drinking Water Quality. Nigerian Industrial Standards, NIS 554, Standards Organization of Nigeria.pp30

United State Environmental Protection Agency (USEPA) (1983). Methods for Chemical analyses of Water andWastes. Epa600/4-79-020 USEPA CincinnatiUNEP

World Health Organization (WHO) (2008). Guidelines for Drinking Water Quality. Third Edition incorporating the first and second addenda volume 1 Recommendations. WHO Geneva, 475-500.

Submitted:

May 25, 2019
Revised:

February 15, 2020
Accepted and published online

April 23, 2020 